\title{
Integration of Multiple Intelligences in Thematic Instructional Kit in Elementary School
}

\section{Komang Widiana ${ }^{1 *}$, I Komang Sudarma², I Ketut Dibia ${ }^{3}$}

\author{
1,2,3 Program Studi Pendidikan Guru Sekolah Dasar, Universitas Pendidikan Ganesha, Singaraja, Indonesia
}

\author{
ART I C LE IN F O \\ Article history: \\ 25 December 2020 \\ Received in revised form \\ 01 January 2021 \\ Accepted 25 January \\ 2021 \\ Available online 03 \\ Pebruari 2021

Kata Kunci:
Perangkat Pembelajaran,
Tematik, Kecerdasan
Majemuk
Keywords:
Instructional Kit,
Thematic, Multiple
Intelligences

\begin{abstract}
A B S T R A K
Pembelajaran yang dilaksanakan di sekolah selama ini cenderung berfokus pada kecerdasan linguistik dan kecerdasan logika-matematika saja. Padahal, setiap siswa memiliki berbagai macam kecerdasan yang disebut kecerdasam majemuk (multiple intelligences). Penelitian ini bertujuan untuk mengembangkan perangkat pembelajaran tematik berorientasi pada kecerdasan majemuk. Penelitian ini merupakan penelitian pengembangan (R\&D) yang mengadaptasi model pengembangan ADDIE (Analyze, Design, Development, Implementation, and Evaluation). Produk perangkat pembelajaran yang dikembangkan dalam penelitian ini berupa Rencana Pelaksanaan Pembelajaran (RPP) dan Lembar Kerja Peserta Didik (LKPD). Pada penelitian ini, uji validitas produk pengembangan hanya dibatasi hingga tahap uji validasi ahli. Data dikumpulkan dengan menggunakan lembar validasi ahli. Hasil penelitian dan pengembangan menunjukkan bahwa berdasarkan hasil uji validitas ahli yang telah dilakukan, diperoleh skor rata-rata penilaian ahli sebesar 4,88 untuk produk RPP dengan kategori sangat baik, dan sebesar 4,80 untuk produk LKPD dengan kategori sangat baik. Berdasarkan hasil tersebut dapat disimpulkan bahwa produk perangkat pembelajaran yang dikembangkan memiliki validitas dan kualitas yang baik untuk dapat diterapkan di sekolah dasar.
\end{abstract}

\begin{abstract}
A B S T R A C T
The learning carried out in schools has been dominated by the development of logic-mathematics intelligence. In fact, every student has various kinds of intelligence called multiple intelligences. This study aims to develop thematic instructional kit oriented to multiple intelligences. This research is a development research (R\&D) which adapts the ADDIE model (Analyze, Design, Development, Implementation, and Evaluation). The instructional kit products developed in this study are in the form of a Lesson Plan (RPP) and Student Worksheets (LKPD). In this study, the product development validity test was only limited to the expert validation test stage. Data were collected using expert validation sheets. The results of research and development show that based on the results of the expert validity test that has been carried out, the average score of expert judgment is 4.88 for RPP products with very good categories, and 4.80 for LKPD products with very good categories. Based on these results, it can be concluded that the instructional kit products developed have good validity and quality to be applied in elementary schools.
\end{abstract}

\section{Introduction}

Teachers are one of the learning components that have a strategic role in realizing learning success in schools (Chodijah et al., 2012; Sudarma et al., 2020; Weizheng, 2019) As the spearhead of learning, teachers are required to be creative in preparing the learning process, one of which is preparing instructional kit (Hess \& Greer, 2016; Septiani et al., 2013; Sunendar, 2017) In preparing the instructional kit, teachers must pay attention to all aspects that affect learning. One aspect that affects learning is the potential diversity of intelligence possessed by students (Setiawan, 2019; Sholeh, 2016).

Intelligence is defined as a person's ability to solve problems or create valuable products in one or more cultural and social environments (Kartikasari \&Widjajanti, 2015; Sholeh, 2016). Various bits of intelligence owned by the students are then termed with multiple intelligences. Until now, nine multiple intelligences are known: linguistic intelligence, mathematical-logical, spatial/spatial intelligence, kinesthetic-body intelligence, musical intelligence, interpersonal, naturalist/environmental, and extension (Fathani, 2016; Melissa, 2016; Sunendar, 2017). Today, the theory of compound intelligence is one of the most important and promising developments in education. The theory of blended intelligence explains 
that no human being is stupid, and every human being has his intelligence. As an important component of learning, teachers should accommodate every intelligence that learners have. One way that can be done is through instructional kit that accommodate every learner's intelligence (Abidin, 2017; Chaerunnisa et al., 2017; Laksmiwati \&Sunendar, 2019).

Instructional kit should be prepared according to learners' characteristics to provide opportunities for learners to develop their potential (Chatib, 2015; Surna \&Pandeirot, 2014; Wicaksono et al., 2014). This can be done by putting together instructional kit that use varied learning strategies to accommodate all students' potential (Suarca et al., 2016; Surna \&Pandeirot, 2014). In line with this, the learning process using strategies that facilitate learners' ability (one of which is compound intelligence) will help educators create a series of learning activities that refer to learning indicators to achieve the expected competencies (Sudarma et al., 2019).

But the conditions on the ground were not what was expected. Based on observations from several related studies, namely: Chaerunnisa et al. (2017); Kartikasari \&Widjajanti (2015); Sudarma et al. (2020); Sunendar (2017), there are still many teachers who have not developed and empowered multiple intelligences in classroom learning. Learning generally still focuses on academic intelligence (linguistics and logic-mathematics). This is seen from the instructional kit made by teachers still do not emphasize on compound intelligence. The instructional kit made by teachers still focus on empowering logicmathematical and linguistic intelligence (Laksmiwati \&Retnowati, 2019).

The existence of the above problems causes the need for a solution to overcome the problem. One solution that can be provided is to develop multiple intelligences-based instructional kit to accommodate every intelligence possessed by learners in learning. The development of learning devices is an effort that is implemented to improve the instructional kit in the field and accommodate every intelligence that students have so that with these efforts, students are motivated and happy in following the learning (Amir, 2013; Laksmiwati \&Sunendar, 2019; Machali, 2014).

Multiple Intelligences is a term or theory of intelligence science that means "Double Intelligence" or "Compound Intelligence" (Amir, 2013). Gardner (2011) defines intelligence as the ability to solve problems and produce products in various settings and real situations. In line with this, the theory of compound intelligence emphasizes individual differences so that in education, it relies heavily on the introduction, recognition, and appreciation of each or more ways learners learn, in addition to the opening, recognition, and appreciation of each learner's interests and talents (H. Gardner \&Hatch, 1989). Multiple intelligences consist of: linguistic intelligence, mathematical logic, spatial-visual, kinesthetic/physical/Carnatic, musical, interpersonal, intrapersonal, and environmental (Gardner, 2011).

Several studies have developed multiple intelligences in learning devices. First, Chaerunnisa et al. (2017) conducted biological learning devices based on compound intelligence on cell concept material in grade XI high school. Furthermore, Wicaksono et al. (2014) also developed English math instructional kit based on blended intelligence theory for grade VIII junior high school. In addition, Laksmiwati \&Retnowati (2019) has developed a geometry learning tool based on compound intelligence for learning in grade VIII junior high school. From some of these studies, there is still no research that conducts multiple intelligences in primary school thematic learning. The development of compound intelligence is important at the basic education level to improve the instructional kit in the field and accommodate every intelligence that students have. With these efforts, students are motivated and happy in following the learning (Susanto, 2005; Wicaksono et al., 2014).

This study aims to develop thematic instructional kit oriented to multiple intelligences and analyze thematic learning device products' feasibility to multiple intelligences. The development of instructional kit is carried out at the grade I elementary school level, namely in theme 6 and sub-theme 1.

\section{Method}

This research used the ADDIE development model (Analysis, design, development, implementation, and evaluation). The selection of this model is based on considering that the ADDIE model is systematically realized and based on the theoretical foundation of learning design (Tegeh \&Kirna, 2013). Addie model provides an opportunity to evaluate at every stage, thus minimizing the lack of products developed (Tegeh et al., 2015). The implementation phase was not implemented due to time and cost constraints and the Situation of the Covid-19 pandemic.

The data collected was data resulting from the validity of instructional kit and advice by experts. Their nature groups all data obtained into two, namely qualitative data and quantitative data. Qualitative data in the form of various inputs, suggestions, and comments from all experts, and quantitative data in the form of scores obtained through instruments in the form of assessment sheets. The assessment 
dimension in developing compound intelligence-oriented learning devices is presented in Table 1 and Table 2.

Table 1. Assessment Indicator of Lesson Plan

\begin{tabular}{|c|c|}
\hline Aspect & Indicator \\
\hline $\begin{array}{l}\text { Completeness and demand of Lesson } \\
\text { Plan following Permendikbud No. } 22 \\
\text { the year } 2016\end{array}$ & $\begin{array}{l}\text { The entirety of Lesson Plan components, according to } \\
\text { Permendikbud No. 22, the year } 2016 \\
\text { Lesson Plan component demand according to Permendikbud } \\
\text { No. } 22 \text { the year } 2016\end{array}$ \\
\hline Subject Matter & The subject matter under KD \\
\hline Time Allocation & $\begin{array}{l}\text { Allocation of time following the requirements for the } \\
\text { achievement of basic competencies }\end{array}$ \\
\hline Learning objectives & $\begin{array}{l}\text { Learning objectives are formulated based on competency } \\
\text { achievement indicators } \\
\text { Formulation of learning objectives meets aspects of ABCD } \\
\text { (Audience, Behavior, Condition, Degree) }\end{array}$ \\
\hline $\begin{array}{l}\text { Basic competencies and competency } \\
\text { achievement indicators }\end{array}$ & $\begin{array}{l}\text { Basic competencies following those in the syllabus } \\
\text { Indicators formulated following basic competencies } \\
\text { Indicator formulation using operational verbs }\end{array}$ \\
\hline Learning materials & $\begin{array}{l}\text { Learning materials contain facts, concepts, principles, and } \\
\text { procedures relevant to the formulation of indicators } \\
\text { Learning methods adapted to the characteristics of learners }\end{array}$ \\
\hline Learning methods & $\begin{array}{l}\text { Learning methods adapted to the basic competencies to be } \\
\text { achieved }\end{array}$ \\
\hline Learning media & $\begin{array}{l}\text { Conformity between selected learning media and learning } \\
\text { methods } \\
\text { Conformity of selected media with indicators of achievement } \\
\text { of competencies and basic competencies }\end{array}$ \\
\hline Learning resources & $\begin{array}{l}\text { Adequacy of learning resources } \\
\text { Steps of multiple intelligences }\end{array}$ \\
\hline Learning steps & $\begin{array}{l}\text { The cuteness of the learning steps } \\
\text { Suitability of time allocation for each learning stage }\end{array}$ \\
\hline $\begin{array}{l}\text { Assessment of learning outcomes } \\
\text { Grammar }\end{array}$ & $\begin{array}{l}\text { Accuracy of the selection of techniques and forms of } \\
\text { assessment } \\
\text { Use of EYD/EBI compliant grammar }\end{array}$ \\
\hline
\end{tabular}

Table 2. LKPD Product Assessment Indicators

\begin{tabular}{ll}
\hline \multicolumn{1}{c}{ Aspect } & \multicolumn{1}{c}{ Indicator } \\
\hline LKPD Identity & Completeness of LKPD identity \\
Working instructions & Clarity of working instructions \\
Learning objectives & Lesson Plan's learning objectives \\
Learning materials & Conformity of materials with learning objectives in LKPD \\
& $\begin{array}{l}\text { Activities in LKPD oriented compound intelligence (multiple } \\
\text { intelligences) }\end{array}$ \\
Activities and steps & Ease of activity steps \\
& Time allocation compatibility \\
Time allocation & The use of appropriate grammar \\
grammar & LKPD illustration depicting teaching materials \\
LKPD design & Layout harmony \\
\hline
\end{tabular}

The analysis techniques used in this study are qualitative and quantitative analysis. A qualitative analysis technique was used to process data of expert test results. This data analysis technique was used by grouping information from qualitative data in the form of inputs, responses, criticisms, and suggestions for improvements contained in the instrument. The results of this analysis were then used to revise the developed products. The quantitative analysis technique was used to process data in the form of numbers obtained through the assessment sheet. The analysis used is a calculated average (mean) formula. Based 
on the average results of the calculation obtained, Benchmark Reference Assessment (PAP) Scale Five was used to interpret the results of data analysis (Koyan, 2011). The guidelines can be found in Table 3 .

Table 3. Benchmark Assessment On a Scale of Five

\begin{tabular}{cc}
\hline Mean & Category \\
\hline $4,01<X \leq 5,01$ & Very Good \\
$3,34<X \leq 4,01$ & Good \\
$2,66<X \leq 3,34$ & Enough \\
$1,99<X \leq 2,66$ & Bad \\
$0,99<X \leq 1,99$ & Very Bad \\
\hline
\end{tabular}

\section{Result and Discussion}

\section{Results}

\section{Needs Analysis Results}

Based on the results of analyzing and reviewing several relevant related kinds of research, namely: Chaerunnisa et al. (2017); Kartikasari \&Widjajanti (2015); Sudarma et al. (2020); Sunendar (2017), there are still many teachers who have not developed and empowered multiple intelligences in classroom learning. Learning generally still focuses on academic intelligence (linguistics and logicmathematics). This was seen from the instructional kit made by teachers that still do not emphasize compound intelligence. The instructional kit created by teachers still focus on empowering logicmathematical and linguistic intelligence.

\section{Expert Feedback}

The instructional kit developed were assessed by experts to obtain input for later improvement. Experts evaluate the device in terms of instructional, design, media, and application. The information given by experts during the development phase were presented in Table 4 and Table 5.

Table 4. Expert Input for Lesson Plan Products

\begin{tabular}{llll}
\hline No. & \multicolumn{1}{c}{ Assessors } & \multicolumn{1}{c}{ Comments/Feedback/Improvement Suggestions } \\
\hline 1 & Content Experts & a. & Creating tables to describe and categorize KI 1-4. \\
& b. & The developed lesson plan involves independent learning \\
& c. & The material contained is following the expected achievements \\
& d. & Assessment is following the desired basic competencies. \\
& e. & The learning steps already reflect the expected achievement of basic \\
& & competencies.
\end{tabular}

Table 5. Expert Input for LKPD Products

\begin{tabular}{ccc}
\hline No. & Assessors & \multicolumn{1}{c}{ Comments/Feedback/Improvement Suggestions } \\
\hline 1 & Content Experts & $\begin{array}{l}\text { If you do not use the 9 compound intelligence, you can fill (what } \\
\text { intelligence is contained in the LKPD that you provide) And the next LKPD. }\end{array}$ \\
2 & Media Experts & $\begin{array}{l}\text { a. Create an attractive and informal LKPD covers } \\
\text { b. In LKPD need to determine the type of intelligence that will be } \\
\text { developed by giving the words" Let's develop your language } \\
\text { intelligence", Let's develop your mathematical intelligence" etc }\end{array}$ \\
& & $\begin{array}{l}\text { c. Typefaces are too formal, use typefaces that are more familiar with } \\
\end{array}$
\end{tabular}




\begin{tabular}{llll}
\hline No. & \multicolumn{1}{c}{ Assessors } & \multicolumn{1}{c}{ Comments/Feedback/Improvement Suggestions } \\
\hline & & & children such as arial, comic sans ms, and the like. \\
3 & Learning Design & a. & Giving an example of creating a response sentence \\
& Experts & b. & Need a clue of what is judged from role playing \\
& c. & Questions need to be given examples of the workmanship \\
\hline
\end{tabular}

The inputs received are then followed up by making revisions to Lesson Plan and LKPD products in accordance with the direction and expert input.

\section{Product Assessment Analysis Results by Experts}

Based on the presentation of device assessment data from three experts and data analysis by knowing the average score of each item of device components, then performed conversion to the average of each product developed using a five-scale PAP conversion table. Conversion data for each product is presented in Table 6 and Table 7.

Table 6. Lesson Plan Product Qualification Data

\begin{tabular}{ccc}
\hline Lesson Plan & Mean & Qualification \\
\hline I & 4,9 & Very Good \\
II & 4,8 & Very Good \\
III & 4,9 & Very Good \\
IV & 4,9 & Very Good \\
V & 4,9 & Very Good \\
VI & 4,9 & Very Good \\
\hline Mean & $\mathbf{4 , 8 8}$ & Very Good \\
\hline
\end{tabular}

Table 7. LKPD Product Qualification Data

\begin{tabular}{ccc}
\hline LKPD & Mean & Qualification \\
\hline I & 4,7 & Very Good \\
II & 4,9 & Very Good \\
III & 4,8 & Very Good \\
IV & 4,9 & Very Good \\
V & 4,8 & Very Good \\
VI & 4,7 & Very Good \\
\hline Mean & $\mathbf{4 , 8 0}$ & Very Good \\
\hline
\end{tabular}

Judging from the data analysis of the Lesson Plan in Table 6, it was known that each Lesson Plan product obtained an average value greater than 4.01. Overall, the Lesson Plan device was 4.88 to get excellent qualification (SB). This showed that Lesson Plan products have excellent validity and quality to be implemented in the learning process.

Judging from the data analysis of the Student Worksheet (LKPD) in Table 7, it was known that each LKPD product obtained an average value greater than 4.01. Overall, the average component of the student worksheet device (LKPD) is 4.80 to get excellent qualification (SB). This shows that LKPD products have excellent validity and quality to be implemented in the learning process.

\section{Discussion}

The instructional kit produced in this development research are in Lesson Plan and worksheets of students (LKPD) oriented multiple intelligences. This learning tool is designed for elementary school grade I students, namely in theme 6 , sub-theme 1 . This developed learning tool accommodates multiple intelligences owned by students so that learning can better accommodate every ability possessed by students. The development of this device was done by adapting the ADDIE development model, but due to time constraints and the Covid-19 pandemic situation, research was limited to the development stage only. The selection of the ADDIE development model was because this model was a systematic development model and suitable for developing instructional kit. This was in line with the opinion of Tegeh \&Kirna (2013), which mentions that the ADDIE model is systematic and has a matches with the theory of learning design. 
Several aspects affect the validity of LESSON PLAN and LKPD product-oriented multiple intelligences, namely the content/content of learning, learning design, and conformity of media used. Based on the aspects of learning content, the excellent validity was influenced by the suitability of the material presented with the formulation of basic competencies, indicators, learning objectives, and aspects of compound intelligence developed at each meeting. This was evidenced by an expert assessment of the content of learning on instrument items about the suitability of materials with competency formulas, indicators, and learning objectives that show excellent criteria. Thus, it can be concluded that the product of multiple intelligences-oriented learning devices has been under the demands of basic competencies, indicators, learning objectives, as well as aspects of compound intelligence that were required to be achieved by students at each meeting. This was in line with the opinions of Chodijah et al., (2012) and Kartikasari \&Widjajanti (2015) who suggested that a good learning tool is a suitable learning tool and accommodates all the demands of the standards (KI/KD/Indicators/Objectives) that have been established before designing the device.

Based on the aspects of learning design, the quality and validity were very well influenced by learning strategies and models that stimulate students' interest and participation in the learning process. In addition, learning steps were made by facilitating various intelligence possessed by learners (not only logical-mathematical intelligence). This was evidenced by an expert assessment of the content of learning on the instrument items on the suitability of strategies/models used and aspects of compound intelligence raised in each meeting that showed excellent criteria. Therefore, these multiple intelligences-oriented instructional kit stimulate students' interest and participation in the learning process. This was in line with the research results conducted by Amir (2013) and Sunendar (2017) , which showed that innovative learning could increase students' participation and interest in the following learning.

From the aspect of conformity of the media used, the designed media must comply with Lesson Plan devices. In this development, LKPD media was designed to clarify learning materials and facilitate teachers in accommodating the compound intelligence owned by students and making it easier for students to learn the material and conduct exercises related to the materials taught. This was evidenced by an expert assessment of the content of learning on the instrument items about the suitability of the media used that showed excellent criteria. Thus, it can be concluded that the product of multiple intelligences-oriented learning devices had used media that suits the needs and standards set and deserves to be applied in learning. This was in line with the opinion expressed by Barlenti et al. (2017) which states that one of the aspects used to assess the feasibility of learning devices before they can be applied is the conformity between the learning process and the media used. The media used must support the learning activities carried out, and make it easier for students to achieve the learning objectives that have been set.

\section{Conclusion}

Based on the results of research and discussion, the average value of Multiple Intelligences oriented learning devices that include Lesson Plan and LKPD, after being converted into a five-scale PAP table Lesson Plan, LKPD has excellent qualifications. Thus, in general, the instructional kit on the resulting flat build topic are very well qualified. These results show that Lesson Plan and LKPD products have excellent validity and quality in the learning process.

\section{References}

Abidin, Z. (2017). Pengembangan Kecerdasan Majemuk (Multiple Intelligences) di Madrasah. Elementary: Jurnal Ilmiah Pendidikan Dasar, 3(2), 120-131. https://doi.org/10.32332/elementary.v3i2.832.

Amir, A. (2013). Pembelajaran matematika dengan menggunakan kecerdasan majemuk (multiple intelligences). Logaritma: Jurnal Ilmu-Ilmu Pendidikan Dan Sains, 1(1). https://doi.org/10.24952/logaritma.v1i01.196.

Barlenti, I., Hasan, M., \& Mahidin, M. (2017). Pengembangan LKS Berbasis Project Based Learning untuk Meningkatkan Pemahaman Konsep. Jurnal Pendidikan Sains Indonesia (Indonesian Journal of Science Education), 5(1), 81-86. http://www.jurnal.unsyiah.ac.id/JPSI/article/view/8415.

Chaerunnisa, V., Syauqiyah, S. G., \& Ekanara, B. (2017). Pengembangan Perangkat Pembelajaran Biologi Berorientasi Pengembangan Kecerdasan Majemuk Siswa Pada Konsep Sel Kelas XI SMA. Biodidaktika: Jurnal Biologi Dan Pembelajarannya, $12(1)$. https: //doi.org/10.30870/biodidaktika.v12i1.2344.

Chatib, M. (2015). Sekolahnya Manusia (Edisi Baru). Kaifa PT Mizan Pustaka. 
Chodijah, S., Fauzi, A., \& Ratnawulan, R. (2012). Pengembangan perangkat pembelajaran fisika menggunakan model guided inquiry yang dilengkapi penilaian portofolio pada materi gerak melingkar. Jurnal Penelitian Pembelajaran Fisika, 1(1). https://doi.org/10.1234/jppf.v1i1.603.

Fathani, A. H. (2016). Pengembangan literasi matematika sekolah dalam perspektif multiple intelligences. Edu Sains: Jurnal Pendidikan Sains Dan Matematika, 4(2). https://doi.org/10.23971/eds.v4i2.524.

Gardner, H. E. (2011). Frames of mind: The theory of multiple intelligences. Hachette Uk.

Gardner, H., \& Hatch, T. (1989). Educational implications of the theory of multiple intelligences. Educational Researcher, 18(8), 4-10. https://doi.org/10.3102\%2F0013189X018008004.

Hess, A. K. N., \& Greer, K. (2016). Designing for engagement: Using the ADDIE model to integrate highimpact practices into an online information literacy course. Communications in Information Literacy. https://doi.org/10.15760/comminfolit.2016.10.2.27.

Kartikasari, A., \& Widjajanti, D. B. (2015). Pengembangan Perangkat Pembelajaran Matematika Berbasis Howard Gardner's Multiple Intelligences Berorientasi pada Kemampuan Koneksi Matematis Siswa Kelas VIII SMP. Seminar Nasional Matematika Dan Pendidikan Matematika UNY, 1031-1040. http://seminar.uny.ac.id/semnasmatematika/sites/seminar.uny.ac.id.semnasmatematika/files/b anner/PM-145.

Koyan, I. W. (2011). Asesmen dalam Pembelajaran. Universitas Pendidikan Ganesha.

Laksmiwati, P. A., \& Retnowati, E. (2019). Pengembangan perangkat pembelajaran geometri berbasis kecerdasan majemuk siswa SMP kelas VIII. Pythagoras: Jurnal Pendidikan Matematika, 14(1), 111. https://journal.uny.ac.id/files/journals/6/articles/26591/submission/layout/26591-687453-LE.pdf.

Laksmiwati, P. A., \& Sunendar, A. (2019). Pembelajaran Matematika Berbasis Kecerdasan Majemuk: Apa dan Bagaimana?(Mathematics Learning Based Multiple Intelligence: What and How?). Jurnal THEOREMS (The Original Research of Mathematics), 3(2), 194-210. https://doi.org/10.31949/th.v3i2.1194.

Machali, I. (2014). Dimensi Kecerdasan Majemuk Dalam Kurikulum 2013. Insania: Jurnal Pemikiran Alternatif Kependidikan, 19(1), 21-45. https://doi.org/10.24090/insania.v19i1.462.

Melissa, M. M. (2016). Pengembangan perangkat pembelajaran topik lingkaran berbasis kecerdasan majemuk gardner berorientasi pada prestasi dan kemandirian belajar. Widya Warta: Jurnal Ilmiah Universitas Katolik Widya Mandala Madiun, 40(2), 296-309. http://portal.widyamandala.ac.id/jurnal/index.php/warta/issue/view/46.

Septiani, D., Ridlo, S., \& Setiati, N. (2013). Pengembangan lembar kerja siswa berbasis multiple intelligences pada materi pertumbuhan dan perkembangan. Journal of Biology Education, 2(3). https://doi.org/10.15294/jbe.v2i3.3098.

Setiawan, A. R. (2019). Literasi Saintifik Berdasarkan Kecerdasan Majemuk dan Motivasi Belajar. Media Penelitian Pendidikan: Jurnal Penelitian Dalam Bidang Pendidikan Dan Pengajaran, 13(2), 126137. https://doi.org/10.26877/mpp.v13i2.4913.

Sholeh, K. (2016). Kecerdasan Majemuk Berorientasi pada Partisipasi Peserta Didik. Pustaka Pelajar.

Suarca, K., Soetjiningsih, S., \& Ardjana, I. E. (2016). Kecerdasan majemuk pada anak. Sari Pediatri, 7(2), 8592. https://www.saripediatri.org/index.php/sari-pediatri/article/download/857/791.

Sudarma, I. K., Pudjawan, K., \& Prabawa, D. G. A. P. (2020). Pelatihan Strategi Pembelajaran Berorientasi Multiple Intelligences Bagi Guru-Guru SD. Proceeding Senadimas Undiksha.

Sudarma, I. K., Tegeh, I. M., \& Suwatra, I. W. (2019). Pelatihan Implementasi Media Pembelajaran Berorientasi Multiple Intelligences Melalui Lesson Study Di Taman Kanak-Kanak. Seminar Nasional Pengabdian Kepada Masyarakat, 538-543.

Sunendar, A. (2017). Perangkat Pembelajaran Matematika Berbasis Teori Kecerdasan Majemuk Apa dan Bagaimana Mengembangkannya. Jurnal THEOREMS (The Original Research of Mathematics), 1(2), 1-12. https://doi.org/10.31949/th.v2i1.577.

Surna, I. N., \& Pandeirot, O. D. (2014). Psikologi Pendidikan 1. Erlangga.

Susanto, H. (2005). Penerapan multiple intelligences dalam sistem pembelajaran. Jurnal Pendidikan Penabur, 4(4), 67-75. https://www.academia.edu/download/33318881/Hal.6775_Penerapan_Multiple_Intillegence_dalam_Sistem_Pembelajaran.pdf.

Tegeh, I. M., Jampel, I. N., \& Pudjawan, K. (2015). Pengembangan buku ajar model penelitian pengembangan dengan model ADDIE. Seminar Nasional Riset Inovatif. 
Tegeh, I. M., \& Kirna, I. M. (2013). Pengembangan Bahan ajar metode penelitian pendidikan dengan addie model. Jurnal Ika, 11(1).

Weizheng, Z. (2019). Teacher-Student Interaction in EFL Classroom in China: Communication Accommodation Theory Perspective. English Language Teaching, 12(12), 99. https://doi.org/10.5539/elt.v12n12p99.

Wicaksono, D. P., Kusmayadi, T. A., \& Usodo, B. (2014). Pengembangan perangkat pembelajaran matematika berbahasa inggris berdasarkan teori kecerdasan majemuk (multiple intelligences) pada materi balok dan kubus untuk kelas VIII SMP. Jurnal Pembelajaran Matematika, 2(5). https://jurnal.fkip.uns.ac.id/index.php/s2math/article/view/4378. 